\title{
The Implementation of Accrual Basis Accounting in Indonesian Local Government
}

\author{
Albertus Theo Jonathan, Khoirul Aswar, Ermawati \\ Universitas Pembangunan Nasional Veteran Jakarta, Indonesia \\ aswar_law@yahoo.com
}

\begin{abstract}
This study is based on the Government Regulation No 71 of 2010 concerning Government Accounting Standards which have been enacted since 2015. In the period of this regulation enactment, there are obstacles that occur and it causes culpabilities in accrual basis accounting reporting. The objective of this study is to discover the factors which affect the accrual basis accounting implementation. Utilizing institutional theory as the theoretical basis to establish the framework that correlate training, communication, educational background, organizational culture, and implementation of accrual basis accounting. This study was conducted using quantitative method in local government of Bekasi. Therefore, this study contributes to regional government in order to able to provide the input in implementing a policy, specifically the Government Accounting Standards; provide information in regard to the obstacles and solutions which affects the implementation accrual basis accounting in Regional Government; and be able to evolve and intensify the application of public sector governance, and also can be function as a suggestion for the public in creating policies and to ensure the fully-implementation in Regional Government.
\end{abstract}

Keywords: Training, Communication, Educational Background, Organizational Culture, and Implementation of Accrual Basis Accounting.

\section{Introduction}

The implementation of accrual basis recording is a transformation that happened in public sector which is indicated by the publication of New Public Management (NPM). NPM is a term that is used in general classification and it is similar to the public sector reform. NPM demands the management of state finances to be more transparent, accountable and be obtained to reveal the relevant information that worthwhile in decision and liability making. This requirement is in line with the advantage of accrual basis accounting implementation. Accrual system is one of NPM product and its implementation is regulated in Government Accounting Standards (GAS). GAS is the principles of accounting that are implemented in compiling and presenting the Government Financial statements. Accrual accounting reform in Indonesia is indicated by the publication of Law of The Republic of Indonesia No. 17 of 2003 on State Finances; and No. 1 of 2004 concerning State Treasury; Government Regulation Number 71 of 2010 concerning GAS; Regulation of the Minister of Home Affairs 64 of 2013 regarding the Implementations of Accrual Based GAS in Regional Governmental (Aswar, 2019). Generally, accrual accounting and reporting have been accepted by countries internationally. In Adhikari \& Gårseth-Nesbakk, 2016) this matter is believing that the advantage of accrual accounting and reporting to various levels and at various levels, that is central government, state and regional governments and social assurance funds. Based on data of Price Waterhouse Cooper (PWC) Annual Report (2015), each of continents in world has implemented accrual accounting even though the continent which has $100 \%$ implementation is only in Oceania.

At the beginning of the implementation of the accrual system in Indonesia, there was many obstacles occurred. Based on data from the Outline of Inspection Results in First Semester of 2016 and outline of Inspection Results in First Semester of 2018, it indicates that there are transactions which are still presented on a cash basis. According to the 2015-2019 National Medium-Term Development Plan (RPJMN), accrualbased implementation in Indonesia is 24 provinces and 300 districts / cities. In the financial statements of 2015, the average score of Regional Government which have implemented Accrual Based Government Accounting Standards was 69.55 (Leksono \& Haryanto, 2017). One of many factors that become the obstacles of accrual accounting implementations is the lack of human resources' capabilities. In order to minimize those obstacle, then trainings towards human resources are required to hold, good communication, excellent educational background, and organizational culture (Ouda, 2008). As the result, qualified and competent human resources will be available to compile and present the accrual-based Government Financial Reports. Furthermore, Aswar and Ermawati (2019) states that there is precondition on the accrual accounting implementation in Indonesia which is work experience, academic qualification. Fadelelmoula (2018) stated 
that an organization which adopts a system has to observe the training factor, because training program give effect on system implementation. Some researchers find out that training have advantage in enhance enduser skills for organizational efforts.

In achieving managerial and performance goals (Ram, Corkindale, \& Wu, 2013), Aswar and Saidin (2018) discovers that there is a positive relation between training and accrual accounting system adoption. This matter is also in line with the argument of Aswar and Saidin (2018b) that is training effects on the accounting accrual implementation. One of the factors causing the failure in a system implementation is the existence of gap in communication (Al-Mashari \& Al-Mudimigh, 2003; Abouzahra, 2011). Almajed \& Mayhew (2013) stated that communication is one of the key factors in the successful implementation of a system. Coordinated communication is an efficient method to define goals, schedules, benefits, and population, and regular advisory to adequacy levels which are really important (Dezdar, 2012). Human Capital theory explain that education imparts knowledge, skills and values to people so therefore they can intense their learning capacity and productivity. Organizational culture includes terms such as values, traditions, policies, business principle, beliefs and confidence of employee about the business system.

Gray (2006) indicated that education also influences the ability to comprehend (including competence of, acquisition, assimilation, transformation and exploitation) and updated knowledge. Eriotis, Stamatiadis and Vasiliou (2012) revealed that clinical educational background will be more depend on formal forms of management and hierarchy so it will be more motivated to adopt the accrual accounting system and reap the expected benefit. Organizational culture can determine whether an implementation of a system can be works or not. Annamalai and Ramayah (2013) declared that organizational cultures are having implication in the system implementation. Aswar and Saidin, (2018) was using moderation variable to measure the relation between the support of top management level, training, and the quality of IT toward the adoption of accrual accounting. This study was conducted with the aim of finding out the relation of training, communication, educational background, organizational culture, and the accrual accounting implementation.

\section{Literature Review and Hypothesis Development}

Institutional Theory and Its Relevance to Legitimizing Accrual Accounting Implementation: Often the spread of accrual-based accounting is often linked to institutional theory in the public sector organization (Modell, 2009, 2013; Jacobs, 2012). This theory has allowed to clarify many important issues related to the reform of the public sector accountants; including development partners, the role of foreign organizations and the distribution of ideas and similar variations results (Ahn et al., 2014; Pollanen \& Loiselle-Lapointe, 2012; Oulasvirta, 2014). In organizational practice, institutional theory examines the effect between persons, culture and the state, and exposes aspects that are incompativle with the 'formal organizations account' (DiMaggio, 1991). Organizations are considered reasonable actors with minimal options, financial, economic, political and structural factors provide the basis to legitimize and promote organizational practices (DiMaggio \& Powell, 1983). Accounting as an organizational practice is embedded in institutional and social context in which it operates (Hopwood, 2000), and thus, the factors affecting and legitimizing the accrual accounting implementation in Indonesian public sector can be identified by using institutional theory.

Using organization as the unit of analysis, institutional theory reveals dissemination at local level (DiMaggio, 1991), the types of economic behavior arise among organizational and how the common roots of internal organizational influence actors to act in some way (Mbelwa, 2015; Scapens, 2006). The institutional theory can be analyzed by an analytical perspective from three logical perspectives which is memetic, coercive, and normative. Coercive isomorphism', is the product of formal and informal pressure exerted by other organizations on organizations depending on the financial resources and cultural aspirations of the individuals embedded in the organization (DiMaggio \& Powell, 1983). Meanwhile, Coercive isomorphism is creating new organizational practices that are rationalised by reference to ritual homogeneity and conformity with other institutions. One of the coercive isomorphism mechanisms is regulatory change by dominating institutions, which often requires that followers change their shape and structure. Jorge et al. (2007) conducted study in public accounting reforms in Portuguese; he argues that the application of accrual accounting has changed local standards and institutionalized new accounting practices. 
The Impact of Training towards Accrual Basis Accounting Implementation: Training gives learners knowledge and skills which are needed for their current occupation (Mondy, 2008). This is in line with the institutional normative isomorphism theory. That training is learning and improving individual abilities of individuals to carry out professional demands. Previous study found that there are impacts between training towards accrual accounting implementation (Dianto, \& Aswar, 2020; Aswar \& Saidin, 2018; Dezdar, 2012; Kusuma \& Fuad, 2013 and Almajed \& Mayhew, 2013). Based on those descriptions, the hypothesis that can be formulated is:

H1: Training has a significant impact towards accrual basis accounting implementation.

Impact of Communication towards Accrual Basis Accounting Implementation: Communication is a process to share information between two or more individuals. The effective communication can provide progress and will affect the implementations of accrual accounting. On institutional theory, communication is important for the effectiveness of groups or organizations and improving employee quality. In accordance with the institutional theory which stated that is communication encouragement will intensify people to communicate between their organizational scope, so that accrual basis accounting implementation run well, as normative isomorphism. Some studies represent a positive relation between communication and accrual accounting implementation, and the level of communication in socialize and applying government accounting standard in line with the level of accrual-based GAS in the related region (Aswar \& Saidin, 2018b; Dezdar, 2012 and Almajed \& Mayhew, 2013). Regarding those elucidations, the hypothesis that can be formulated is: H2: Communication has a significant impact towards accrual basis accounting implementation.

Impact of Educational Background towards Accrual Basis Accounting Implementation: Education imparts knowledge and skills to the individual so it intensifies the learning capacity and productivity. Gray (2006) shows that education also influences the ability to absorb (including the ability to acquire, simulate, transform and exploit) and new knowledge. According to the institutional normative isomorphism theory, educational background has a role in individual skills to absorb, comprehend and apply a policy or procedure in an organization; in this case it is accrual basis accounting implementation. Referring those descriptions, the hypothesis that can be formulated is:

H3: Educational background has a significant impact towards accrual basis accounting implementation.

Organizational Culture Moderates the Impact of Training towards Accrual Basis Accounting Implementation: Organizational culture is a perception of practices or values that encourage the organization to strive goals. While its practices, organization often goes through obstacles wherein the lack quality of human resources' capabilities that are available. Organizational culture encourages and emphasize that human resources can improve their quality and skills. Organization that embraces such a culture, then human resources are encouraged to be able to comply and carry out the training to support the achievement of objectives. Therefore, training can provide benefits and achieved objectives; in this case it is accrual basis accounting implementation. This case is in accordance with institutional normative isomorphism theory regarding professional abilities that can improve the process of accrual basis accounting system implementation in regional government. Regarding those commentaries, the hypothesis that can be formulated is:

H4: Organizational culture moderates the impact of training towards accrual basis accounting implementation.

Organizational Culture Moderates the Impact of Communication towards Accrual Basis Accounting Implementation: Organizational culture implementation is related to a good and maintained level of communication. In order to achieve the goals, communications between individuals in organization are needed. Regarding institutional theory, the implementation of a proper communication can improve the individual quality; in this context is normative isomorphism. Implementation of organizational communication culture can intensify the recent system implementation. Referring those elucidations, the hypothesis that can be formulated is:

H5: Organizational culture moderates the impact of communication towards accrual basis accounting implementation. 
Organizational Culture Moderates the Impact of Educational Background towards Accrual Basis Accounting Implementation: Organizational culture also often associated with a good teamwork system. The existence of organizational culture, it can assist certain parties/individuals that have a lower background or who are not appropriate to the related scope of work become more ingenious. It is in accordance with institutional normative isomorphism theory that is based on professional demands. So that organizational culture in the matter of team work can assist individual who lack in comprehension, in this context is to assist individuals in accrual basis accounting implementation. Based on those descriptions, the hypothesis that can be formulated is:

H6: Organizational culture moderates the impact of educational background towards accrual basis accounting implementation.

Figure 1: Research Model

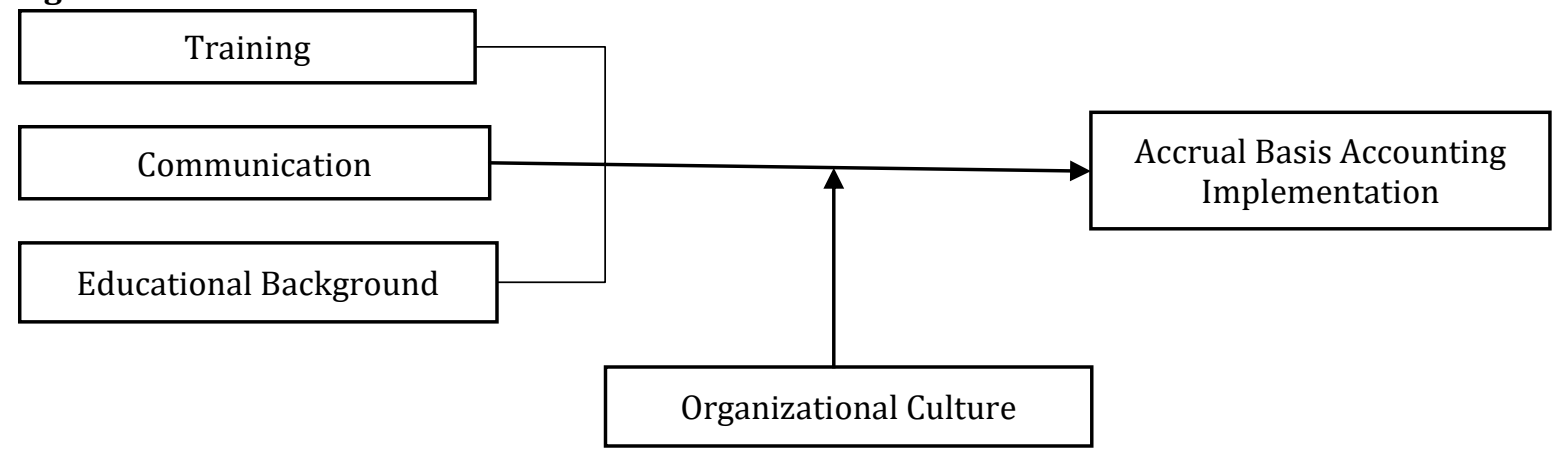

\section{Proposed Method}

This study recommends an appropriate method to verify the conceptual framework which is proposed for empirical studies where data can be collected from respondents. Population target in this study are Head of Finance Subdivision and Staff at Regional Government Organization of Bekasi City. The decision to pick Head of Finance Subdivision and Staff at Regional Government Organization of Bekasi City as population target in this study because they are the responsible parties in compiling and presenting the financial reports. Furthermore, sample was collected by using census sampling technique. In Table 1 figure out the distribution of 44 subdivisions in Regional Government Organization of Bekasi City.

Table 1: List of Local Government of Bekasi

\begin{tabular}{ll}
\hline Local Government Organization & Head of Planning Subdivision \\
\hline Regional Committee & 6 \\
Local Agencies & 21 \\
Inspectorate & 1 \\
Sub-District & 12 \\
Regional Public Hospital & 1 \\
Civil Service Police Unit & 1 \\
Regional Secretariat & 1 \\
Regional Representative Council Secretariat & 1 \\
\hline Total Head of Planning Subdivision & $\mathbf{4 4}$ \\
\hline
\end{tabular}

\section{Conclusion}

The objective of this study is to discover the relation of training, communication, educational background, organizational culture, and accrual accounting implementation in Indonesian local government. This study required to be done by considering that implementation of accrual basis accounting system in Indonesia is relatively new yet, and the discovery of obstacles that might be happened because of training, communication, educational background, and organizational culture. The findings of this study are expected to provide some inputs in implementing a policy especially Government Accounting Standard, provide information in regard to obstacles and solutions that affect accrual basis accounting system implementation 
in Regional Government, can develop and improve public sector governance and also can be worthy as a recommendation for the public in creating policy and assure full implementation in Regional Government.

\section{References}

Abouzahra, M. (2011). Causes of failure in Healthcare IT projects. 3rd International Conference on Advanced Management Science, 19, 46-50.

Adhikari, P. \& Gårseth-Nesbakk, L. (2016). Implementing public sector accruals in OECD member states: Major issues and challenges. Accounting Forum, 40(2), 125-142.

Ahn, P., Jacobs, K., Lim, D. W. \& Moon, K. (2014). Beyond self-evident: Recognising the problematic political context of accrual accounting adoption in South Korea. Financing, Accounting \& Management, 30(1), 25-48.

Al-Mashari, M. \& Al-Mudimigh, A. (2003). ERP implementation: Lessons from a case study. Information Technology \& People, 16(1), 21-33.

Almajed, A. I. \& Mayhew, P. (2013). The critical success factors of IT projects in Saudi Arabian public organizations. Entrepreneurship Vision 2020: Innovation, Development Sustainability, and Economic Growth - Proceedings of the 20th International Business Information Management Association Conference, IBIMA 2013, 1, 849-856.

Annamalai, C. \& Ramayah, T. (2013). Does the organizational culture act as a moderator in Indian enterprise resource planning (ERP) projects? Journal of Manufacturing Technology Management, 24(4), 555587.

Aswar, K. \& Saidin, S. Z. (2018). The Influencing Factors on the Level of Accrual Accounting Adoption: A Conceptual Approach. Romanian Economic Business Review, 13(2), 30-36.

Aswar, K. \& Saidin, S. Z. (2018b). Accrual Accounting Adoption in Java Municipalities: An Empirical Investigation. International Journal of Business and Economic Sciences Applied Research (IJBESAR), 11(3), 24-30.

Aswar, K. (2019). Factors on the accrual accounting adoption: Empirical evidence from Indonesia. International Journal of Business and Economic Sciences Applied Research (IJBESAR), 12(3), 36-42.

Aswar, K. \& Ermawati, E. (2019). Pengadopsian akuntansi akrual di pemerintah daerah (Studi kasus pada provinsi Banten). Equity, 22(1), 62-74.

Badan Pemeriksa Keuangan Republik Indonesia. (2016). Ikhtisar Hasil Pemeriksaan Keuangan Semester I 2016, 420.

Badan Pemeriksa Keuangan Republik Indonesia. (2018). Ikhtisar Hasil Pemeriksaan Keuangan Semester I 2018. Indeks Hasil Pemeriksaan Semester 1 Tahun 2018, 470.

Badan Pemeriksa Keuangan Republik Indonesia. (2019). Ikhtisar Hasil Pemeriksaan Keuangan Semester I, 426.

Dezdar, S. (2012). Strategic and tactical factors for successful ERP projects: insights from an Asian country. Management Research Review, 35(11), 1070-1087.

Dianto, A. W. \& Aswar, K. (2020). Assessing accrual accounting implementation in Cianjur regency: An empirical investigation. International Journal of Business and Economic Sciences Applied Research (IJBESAR), 13(1), 7-13.

DiMaggio, P. (1991). Constructing an organizational field as a professional project: The case of US art museums. In Powell, W.W. and DiMaggio, P. (Eds.), Institutional Theory in Organization Studies, the University of Chicago Press, Chicago, 267-292.

DiMaggio, P. J. \& Powell, W. W. (1983). The iron cage revisited: Institutional isomorphism and collective rationality in organizational fields. American Sociological Review, 48(2), 147-160.

Eriotis, N., Stamatiadis, F. \& Vasiliou, D. (2012). Assessing Accrual Accounting Reform in Greek Public Hospitals: An Empirical Investigation. SSRN Electronic Journal, 4(1), 153-184.

Fadelelmoula, A. A. (2018). The Effects of the Critical Success Factors for ERP Implementation on the Comprehensive Achievement of the Crucial Roles of Information Systems in the Higher Education Sector. Interdisciplinary Journal of Information, Knowledge, and Management, 13, 021-044.

Gray, R. (2006). Social environmental and sustainability reporting and organizational value creation? Whose value? Whose creation? Accounting, Auditing and Accountability Journal, 19(6), 793-819.

Hopwood, A. G. (2000). Understanding financial accounting practice, Accounting, Organizations and Society, 25, 763-766. 


\section{Journal of Economics and Behavioral Studies (ISSN: 2220-6140)}

Vol. 12, No. 4, pp. 67-72, August 2020

Jacobs, K. (2012). Making sense of social practice: theoretical pluralism in public sector accounting research. Financial Accountability \& Management, 28(1), 1- 25.

Jorge, S. M., da Costa Carvalho, J. B. \& Fernandes, M. J. (2007). Governmental accounting in Portugal: why accrual basis is a problem. Journal of Public Budgeting, Accounting \& Financial Management, 19(4), 411-446.

Kusuma, M. I. Y. \& Fuad. (2013). Analisis faktor-faktor yang mempengaruhi tingkat penerapan akuntansi akrual pada pemerintah, 2(3), 1-14.

Leksono, B. \& Haryanto, H. (2017). Evaluasi Penerapan Standar Akuntansi Pemerintahan (SAP), Akrual Dalam Penyusunan Laporan Keuangan Tahun 2014 Dan 2015 Pada Pemerintah Daerah Di Indonesia, 6(1), 15-21.

Mbelwa, L. (2015). Factors influencing the use of accounting information in Tanzania local government authorities (LGAs): an institutional theory approach. Research in Accounting in Emerging Economies, $15,143-177$.

Modell, S. (2013). Making sense of social practice: Theoretical pluralism in public sector accounting research: A comment. Financial Accountability \& Management, 29(1), 99-110.

Mondy, R. W. (2008). Manajemen Sumber Daya Manusia. Jakarta: Erlangga.

Ouda, H. A. G. (2008). Towards A Generic Model for Government Sector Reform: The New Zealand Experience. International Journal on Governmental Financial Management, 2, 91.

Oulasvirta, L. (2014). The reluctance of a developed country to choose International Public Sector Accounting Standards of the IFAC. A critical case study. Critical Perspectives on Accounting, 25(3), 272-285.

Pollanen, R. \& Loiselle-Lapointe, K. (2012). Accounting reform in the government of Canada: Exploratory evidence on accrual accounting adoption and impact. Financial Accountability and Management, 28(4), 359-377.

Ram, J., Corkindale, D. \& Wu, M. L. (2013). Implementation critical success factors (CSFs) for ERP: Do they contribute to implementation success and post-implementation performance? International Journal of Production Economics, 144(1), 157-174.

Scapens, R. (2006). Understanding management accounting practices: a personal journey. The British Accounting Review, 38(1), 1-30. 